\title{
MICHAEL MONAHAN AND HIS LITTLE KNOWN LITTLE MAGAZINE
}

\section{BY HERBERT F. SMITH}

\section{1}

1HE first decades of this century were, in terms of literature, an exciting period of experimentation, revolt, re-evaluation. American literary innovators were fanning a blaze that they hoped would consume the piles of Victorian gingerbread that had been accumulating in American literature for half a century. Not the least of these, though among the least remembered, was Michael Monahan, a revolutionist in letters who, from I904 to I9I6, published a magazine that had an influence on American literature that probably extended beyond its meager circulation.

Monahan's apprenticeship to literature was an unusual one. He was born in County Cork, Ireland, on April 6, I 865. His father, a schoolmaster, gave him perhaps a little more education than was customary for a youth of that place and time. Nonetheless, it was doubtless more his native talent than his education that prompted the editor of the Albany Press to give him a job as a reporter when he emigrated to this country in 1887 . By 1892 he had learned his trade well enough to be chosen as a staff writer for the Democratic National Convention of that year. The impression he made upon an Albany friend of that period helps to explain why he was not satisfied with such limited success:

He was a unique figure. I think his poetic soul revolted at the details of newspaper work and that he preferred to let his imagination soar than to tie himself to plain reporting. . . . Careless in his dress, Michael had a hearty contempt for convention. His masterly way of expressing his mind, however, had a charm that discounted outward appearances. ${ }^{1}$

For some time he free-lanced in New York and the West, returning to Albany in 1896 . At that time he became secretary to the mayor of Albany, apparently spending his time at work writing critical barbs against the opposition and his spare time reading the new prose and poetry that was beginning to be heard in this country. In I900,

\footnotetext{
1 Joseph A. Lawson, quoted in an interview in the Albany Daily Press and Knicker-
} bocker, December 2, I 933 . 
determined to leave politics and devote all his time to literature, he joined Elbert Hubbard's colony in East Aurora, New York.

The three years Monahan spent with Hubbard supplied his postgraduate training in literature. He contributed to and helped to edit The Philistine, continued his reading, and listened to stories of another literary revival then going on in New York City. By I903 the "sage of East Aurora" was getting on his nerves; there is even a somewhat documented tradition that he once kicked Hubbard down a flight of stairs. ${ }^{2}$ At any rate, he went to New York where he founded The Papyrus in I 904. It soon foundered, and he moved to East Orange, New Jersey, in 1907. There he received some new backing and continued the magazine to I9I4, moving back to New York in I9ro. In I9I4 the name of the magazine was changed to The Phoenix, suggesting only one of the several times it rose from its own ashes of debt and diminished subscriptions. This renewed vigor lasted only until i9i6, however, when both The Phoenix and its editor retired from active and independent support of the new literature. Monahan then drifted into conservatism and hack writing for several patrons, including Jacob Ruppert, for whom he wrote Dry America in I 922. He died November 23, I 933, in New York.

Today Monahan is almost completely forgotten; few of the standard literary biographical and reference books mention his name, ${ }^{3}$ and his many books and periodicals are as unwanted as they are hard to find. While cronies of his years of glory at Mouquin's and Delmonico's-Huneker, Richard Le Gallienne, Jack London, and many others-have secured their respective niches, Monahan's contribution to the literary revolution of our century is all but ignored. Although the audience he reached was never as extensive as that of Huneker, for example, his magazine did provide a stage for some of the writers who have shaped our literature, and his criticism helped to make the American public receptive to their ideas.

The Rutgers University and Douglass College Libraries have, between them, nearly a complete file of Monahan's two magazines,

\footnotetext{
${ }^{2}$ Information supplied by Maurice Monahan, Michael's son, New York City. Michael Monahan and Hubbard were cautious friends in later life, although Monahan took occasional potshots at The Philistine in his magazines.

3 The most complete description of The Papyrus and The Phoenix is in Fred J. Hoffman, Charles Allen, and Carolyn F. Ulrich, The Little Magazine, $A$ History and a Bibliography (Princeton, N.J., I 946), pp. 237 and 245. No biographical reference work does more than mention Monahan, and few indeed do that.
} 
The Papyrus and The Phoenix. The file represents the major accomplishments of Monahan's career as editor, publisher, and principal contributor to his own magazine. Although a good deal of the format of both magazines obviously is derived from Hubbard's The Philistine, the contents bear out Monahan's subtitle, "A Magazine of Individuality." Each issue included thirty-two pages of text along with a wrap holding whatever advertising Monahan was able to garner (usually for off-beat books published by Monahan himself or by sympathetic publishing companies). Of these thirty-two pages nearly one-half often were devoted to "Side Talks by the Editor." Besides these, Monahan habitually attached aphoristic tailpieces to regular articles, stories, and poems that did not fill whole pages. His longer contributions are by no means limited to the literary scene in their scope, but literature was one of his favorite subjects, quite naturally. Often his literary articles would begin as reviews of new books, but invariably they ended as more definitive, if subjective, evaluations of whatever man and work were being considered.

Other subjects favored by Monahan in his longer essays were American morals, particularly those of New York City, drinking, in which he shows himself to be temperate, "for an Irishman," and religion, in which his Roman Catholicism is revealed to be far less than perfect. On these and any other subjects that tempted his pen he is invariably witty, opinionated, but gifted with that most important ingredient of the familiar essay, something to say. $\mathrm{He}$ shows himself, fifty years later, to have had quite a modern cast of thought about most matters not connected with literature, and some of his opinions have not yet lost the power to shock.

But it is his literary criticism by which he must stand or fall as editor and writer. These are perhaps not quite so iconoclastic as those of most of his friends, nor so consistent. Sampling the opinions given in The Papyrus and The Phoenix, we find that he disapproved of Henry James, thought him a literary snob and an advocate of fustian language; he was sure Oscar Wilde's works would outlive his disgrace and that it was improper to condemn a man's works for his conduct; he wrote that Ibsen was "a great and solitary figure in his chosen province of art," but that, like Osvald Alving in Ghosts, he needed more of "the sun of life." $\mathrm{He}$ defended Poe (on much

${ }^{4}$ The Papyrus, n.s., Vol. III (July-August, 1908), 31-32. 
the same grounds as his defense of Wilde), and urged the literary merits of Lafcadio Hearn and Guy de Maupassant. Irish poets and playwrights, particularly Yeats and Synge, received his partisan support both in the pages of The Papyrus and The Phoenix and in his Nova Hibernia. ${ }^{5}$ Later in his life he urged the merits of Padraic Colum, who might be considered a protégé of his. ${ }^{6}$ At the same time, however, he voiced approval of the weaker realism of W. D. Howells, and found words of praise for that supposed bastion of the genteel tradition, Century Magazine.

Perhaps a better testament of his literary leanings are the authors who appeared in the pages of The Papyrus and The Phoenix. The list suggests the same kind of imbalance between the old and the new, a preponderance of the forerunners of the new literature only slightly offset by more typically nineteenth century names.? The most frequent contributors were Guy de Maupassant, Lafcadio Hearn, and Benjamin de Casseres, who was one of Monahan's best friends. Others whose names appear frequently in his magazines are Gorky and Andreyev, Heinrich Heine, the Syrian poet Ameen Rihani, André Gide, Theofile Gautier, Alphonse Daudet, Anatole France, Charles Baudelaire, Jack London, George Bernard Shaw, Swinburne, W. E. Henley, Galsworthy, A. E. Housman, and Richard Le Gallienne. A cosmopolitan list, to be sure, and one that any periodical might well be proud of, but offset somewhat by other names appearing less frequently-E. C. Stedman, Julian Hawthorne, Austin Dobson, and Bliss Carman, for example-that are of less significance to twentieth century literature.

A third indication of the scope and content of The Papyrus and The Phoenix is the commentary of Monahan's contemporaries about the magazine. These he gathered and printed in each issue under such headings as "Congratulatory," "Scrambled Appreciations," "Indifferent Modest," and the like. Like Walt Whitman, he salted the favorable comments with unfavorable ones. Next to the St. Louis

\footnotetext{
${ }^{5}$ Nova Hibernia: Irish Poets and Dramatists of Today and Yesterday (New York, $1914)$.

${ }^{6}$ See Padraic Colum, "A Ballade Written on Michaelmas Day and Addressed to Michael Monahan Who Had Undergone an Operation," Saturday Review of Literature, Vol. X (October 28, 1933), 22 I.

${ }^{7}$ Almost certainly, Monahan paid little or nothing for contributions. Most of the text, aside from that written by the editor, consists of reprints, but there is a certain amount of original material included in the magazines.
} 
Mirror's encomium, “Michael Monahan is a master of English, and when he sweeps with graceful swing down from the lightning-litten heights of vituperation to the tranquil valleys of sentiment, he soothes us in a Dorian mood of lutes and soft recorders," we find Harry Thurston Peck's comment: "an effective censorship would have prevented this misfortune." But the printed excerpts are overwhelmingly congratulatory and span a wide range of American opinion. The July, I907, issue, for example, carries congratulatory messages from these sources: the London Academy, Richard Le Gallienne, James Huneker, Jack London, Bliss Perry, Dr. W. J. Rolfe, Oliver Leigh, the Chicago Neres, Leonard D. Abbott (associate editor of Current Literature), Edwin Markham, Edmund Clarence Stedman, and Motonsuke Kimura.

But even the generally good reception of the magazine in the many areas suggested by these appreciative comments could not keep the magazine going. Monahan was entirely dependent upon his pen for his living, and The Papyrus and The Phoenix were financed only by the one dollar to $\$ \mathrm{I} .25$ per year subscription rate. Since the circulation was never over a few thousand, Monahan never did more than break even as a magazine editor. Mere hope for profit, therefore, could not have kept the magazine alive for its thirteen years, but by I9I 6 Monahan had lost identity with the later phases of the literary movement he had helped to foster, and the abandonment of the magazine probably caused him very little regret. Nevertheless, The Papyrus and The Phoenix, while they lasted, were a powerful force in support of the literary revolution of this century. 